\title{
PENGARUH INISIASI MENYUSU DINI TERHADAP JUMLAH PERDARAHAN PASCA PERSALINAN
}

\author{
Sumarah $^{1}$, Mohammad Hakimi ${ }^{2}$, Shinta Prawitasari ${ }^{3}$
}

\begin{abstract}
Background: Mortality and morbidity among women during pregnancy and labour are a major problem in poor and developing countries including Indonesia. The prevalence of postpartum hemorrhage is between $2-11 \%$ out of all childbirth. Postpartum hemorrhage is the main cause of maternal mortality (28\%). Maternal mortality mainly occurs within the first 4 hours after childbirth. Uterus contraction after childbirth greatly minimizes the risk of hemorrhage. Early breastfeeding initiation stimulates the back of hypofiche gland to produce oxytoxin that ignites womb muscle contraction so that the risk for the prevalence of postpartum hemorrhage can be minimized.

Objective: To identify the impact of early breastfeeding initiation to the amount of postpartum hemorrhage. Method: The study was observational with prospective cohort design. Subject of the study were normal partum mothers at Sleman Hospital taken using non probability with consecutive sampling technique (62 samples). Data analysis used univariate with frequency distribution and percentage, bivariate with independent t-test and multivariate with linear regression.

Result and Discussion: Average amount of blood in postpartum mothers that practised early breastfeeding initiation (EBI) was lower than those without EBI. The average amount of hemorrhage in mothers that practice $\mathrm{EBI}$ was $77,26 \pm 33,6 \mathrm{cc}$, and in mothers that did not practiced EB was $115,4 \pm 31,0 \mathrm{cc}$. Average difference in the amount of hemorrhage in the two groups was $-38,1 \mathrm{cc}$. This difference was statistically significant with $p<0,05$ $(p=0,000), 95 \% \mathrm{Cl}=-54,6--21,7$. External variables, either age, parity or education of mothers, had no significant association with the amount of postpartum hemorrhage $(p>0,05)$.

Conclusion: $\mathrm{EBI}$ affected the amount of postpartum hemorrhage. Average amount of postpartum hemorrhage in mothers that practiced practised EBI was 38,1 cc less than in those that did not practise EBI.
\end{abstract}

Keywords: postpartum, early breastfeeding initiation, skin to skin contact

\begin{abstract}
ABSTRAK
Latar Belakang: Mortalitas dan morbiditas pada wanita selama kehamilan dan persalinan adalah masalah besar di negara-negara miskin dan berkembang termasuk Indonesia. Prevalensi perdarahan postpartum adalah 2-11\% dari semua persalinan. Perdarahan postpartum merupakan penyebab utama kematian ibu (28\%). Kematian ibu terutama terjadi dalam 4 jam pertama setelah melahirkan. Kontraksi rahim setelah melahirkan sangat meminimalkan risiko perdarahan. Inisiasi menyusui dini merangsang bagian belakang kelenjar hypofiche untuk menghasilkan oxytoxin yang memicu kontraksi otot rahim sehingga resiko untuk prevalensi perdarahan postpartum dapat diminimalkan.

Tujuan: Untuk mengidentifikasi dampak dari inisiasi menyusui dini terhadap jumlah perdarahan postpartum. Metode: Jenis penelitian ini adalah observasional dengan rancangan kohort prospektif. Subyek penelitian adalah ibu yang melahirkan normal di Rumah Sakit Sleman diambil menggunakan non probability dengan teknik pengambilan sampel berturut-turut ( 62 sampel). Analisis data yang digunakan univariat dengan distribusi frekuensi dan persentase, bivariat dengan $t$-test independen dan multivariat dengan regresi linier.

Hasil dan Pembahasan: Jumlah rata-rata darah pada ibu pasca melahirkan yang dilakukan tindakan inisiasi menyusui dini (IMD) lebih rendah dibandingkan mereka yang tidak dilakukan IMD. Jumlah rata-rata perdarahan
\end{abstract}

\footnotetext{
Poltekes Yogyakarta.

2,3 Bagian Obstetri dan Ginekologi, Fakultas Kedokteran, Universitas Gadjah Mada
} 
pada ibu yang berlatih IMD adalah 77,26 $\pm 33,6 \mathrm{cc}$, dan pada ibu yang tidak melakukan IMD adalah $115,4 \pm 31,0$ cc. Rata-rata perbedaan jumlah perdarahan pada kedua kelompok adalah -38,1 cc. Perbedaan ini secara statistik signifikan dengan $p<0,05(p=0,000), 95 \% \mathrm{Cl}=54,6-21,7$. Variabel eksternal, baik usia, paritas atau pendidikan ibu, tidak memiliki hubungan yang signifikan dengan jumlah perdarahan postpartum dengan $p>0,05$.

Kesimpulan: IMD mempengaruhi jumlah perdarahan postpartum. Jumlah rata-rata perdarahan postpartum pada ibu yang dilakukan IMD adalah 38,1cc lebih sedikit dibanding mereka yang tidak berlatih IMD.

Kata kunci: postpartum, inisiasi menyusui dini, kontak kulit dengan kulit

\section{PENDAHULUAN}

Mortalitas danmorbiditas pada wanita hamil dan bersalin merupakan masalah yang besar di negara sedang berkembang seperti Indonesia. Penyebab utama kematian ibu di Indonesia adalah perdarahan yang mencapai $28 \% .{ }^{1}$ Kejadian perdarahan pasca salin berkisar antara 2-11\% dari seluruh persalinan. ${ }^{2}$ Hampir 30\% penyebab kematian langsung ibu di dunia karena perdarahan dan sebagian besar terjadi pada periode pasca salin. ${ }^{3}$ Di beberapa negara paling sedikit 25\% dari seluruh kematian ibu disebabkan oleh perdarahan, proporsinya berkisar antara $<10 \%$ sampai dengan $60 \% .{ }^{4}$ Sekitar 14 juta kasus perdarahan, terjadi pada kehamilan setiap tahunnya dan paling sedikit 128.000 perempuan tersebut meninggal akibat perdarahan. Kematian tersebut sebagian besar terjadi dalam waktu 4 jam setelah melahirkan. ${ }^{4,5,6}$

Kematian ibu diperkirakan $60 \%$ terjadi pada masa nifas dan 50\% nya terjadi dalam 24 jam pertama. ${ }^{7}$ Departemen Kesehatan RI telah melakukan upaya untuk mengatasi hal tersebut dengan meningkatkan pelayanan kesehatan ibu dan bayi baru lahir dengan pendekatan making pregnancy safer (MPS) yang diprakarsai oleh World Health Organization (WHO). ${ }^{8}$

Menyusui dini menyebabkan perangsangan pada kelenjar hipofise bagian belakang yang dapat mengeluarkan hormon oksitosin yang berfungsi memacu kontraksi otot rahim. ${ }^{9}$ Dengan inisiasi menyusu dini (IMD) diharapkan bisa membantu kontraksi uterus menjadi lebih baik karena adanya rangsangan oksitosin oleh hisapan bayi. Adanya kontraksi uterus yang adekuat akan mencegah terjadinya perdarahan pasca salin. ${ }^{10}$ Dengan IMD akan terjadi hentakan, sentuhan, dan jilatan bayi yang akan merangsang kelenjar hipofise melepaskan oksitosin yang membantu uterus berkontraksi, sehingga mencegah perdarahan pasca salin dan mempercepat pengeluaran plasenta. ${ }^{11}$

IMD menimbulkan kontak kulit ibu dan kulit bayi dengan optimal. Penelitian menunjukkan pada saat 1 jam pertama setelah bayi berbaring di dada ibu, bayi akan mengikuti pola yang sama dengan gerakan tangan untuk menemukan dan merangsang payudara ibunya sehingga akan lebih banyak oksitosin yang dikeluarkan. ${ }^{12}$

Pada tahun 2008, jumlah kematian ibu bersalin akibat perdarahan di Propinsi DIY sebanyak 13 orang, yang terdiri atas Bantul 4 orang (30,7\%), Kulonprogo 2 orang $(15,4 \%)$, Gunungkidul 3 orang $(23,1 \%)$ dan Sleman 4 orang $(30,7 \%)$. Penyebab kematian terbanyak dikarenakan perdarahan pada saat persalinan. ${ }^{13}$

Survei awal pada bulan Januari 2010 di Rumah Sakit Umum Daerah (RSUD) Sleman, diketahui bahwa jumlah rata-rata persalinan per bulan 140 orang. Jumlah kejadian perdarahan pasca salin pada tahun 2006 sebanyak 43 kasus (4,2\%) dari 1027 persalinan, tahun 2007 sebesar 42 kasus (4,0\%) dari 1046 persalinan, tahun 2008 sebesar 36 kasus (3,5\%) dari 1018 persalinan, dan tahun 2009 sebesar 24 kasus (2,3\%) dari 1024 persalinan yang ada. Pada persalinan normal sebagian besar sudah dilaksanakan IMD tetapi belum dilakukan secara maksimal, yaitu sudah melaksanakan kontak kulit ibu dan bayi dalam 
proses menyusu dini tetapi belum dilakukan selama satu jam kelahiran. IMD di RSUD Sleman telah dilakukan sejak bulan Januari 2009. Dari data yang diperoleh kejadian perdarahan pada persalinan sebelum dilakukan IMD sebesar 3,5\% dari jumlah persalinan yang ada, sedangkan setelah dilakukan IMD turun menjadi 2,3\%.

Berdasarkan uraian tersebut diatas maka dirumuskan permasalahan penelitian "Bagaimanakah pengaruh IMD terhadap jumlah perdarahan pasca salin di RSUD Sleman ?"

\section{METODE}

Penelitian ini merupakan penelitian observasional dengan rancangan kohort prospektif dan pendekatan kuantitatif. Pada studi kohort prospektif variabel bebas diidentifikasi dahulu kemudian diikuti secara prospektif selama periode tertentu. Dalam penelitian ini variabel yang akan diuji adalah inisiasi menyusu dini dan jumlah perdarahan pasca salin di RSUD Sleman. Populasi penelitian ini adalah semua ibu bersalin di RSUD Sleman sejak minggu pertama April sampai minggu ke empat Juni 2010. Sedangkan subjek penelitiannya adalah ibu bersalin normal yang memenuhi kriteria inklusi dan eksklusi. Pengambilan sampel secara non probability sampling dengan teknik consecutive sampling. Perkiraan besar sampel dalam penelitian ini menggunakan rumus perhitungan untuk pengujian hipotesis dua rata-rata populasi dengan kemaknaan $(\alpha=0,05)$. Besar sampel pada penelitian ini sebanyak 62 subjek. Variabel yang diteliti meliputi variabel bebas IMD, variabel terikat jumlah perdarahan pasca salin dan variabel luar usia, paritas dan pendidikan ibu. Penelitian ini menggunakan data primer yang berupa data kuantitatif. Teknik pengumpulan data dengan observasi melalui pengamatan, pengukuran dan pemeriksaan langsung pada ibu bersalin yang dilaku-kan inisiasi menyusu dini, kemudian dilakukan penghitungan volume darah yang keluar dengan cara menimbang pembalut yang digunakan. Volume darah dihitung dengan membandingkan berat pembalut sesudah digunakan selama 2 jam setelah plasenta lahir dikurangi berat pembalut sebelum digunakan. Hasilnya dimasukkan dalam format pengumpulan data. Pengumpulan data dilakukan oleh peneliti sendiri dibantu tim bidan yang ada di ruang bersalin RSUD Sleman. Instrumen yang digunakan dalam pengukuran volume darah pada pasca persalinan adalah: timbangan elektrik, pembalut dengan berat $38 \mathrm{gr}$ dan daya tampung 500 cc. Sedang cara mengukur perdarahan dengan menampung darah pada setelah plasenta lahir dengan menggunakan pembalut yang telah ditentukan, kemudian setelah 2 jam pembalut diambil, ditimbang dan dikurangi berat pembalut sebelum digunakan kemudian dihitung beratnya. Penghitungan dengan menggunakan rumus $1 \mathrm{gr}=1$ cc cairan. Analisis data yang dilaku-kan meliputi: analisis univariabel, bivariabel dan multivariabel. Uji statistik yang digunakan adalah uji $t$, oneway anova dan uji chi-square serta regresi linier dengan tingkat kemaknaan $p<0,05$ dan confidence interval (Cl) 95\%.

\section{Analisis Univariat}

Tahun 2009 jumlah pengunjung umum di RSUD Sleman sebanyak 48.774 orang, jumlah pasien rawat inap sebanyak 9.923 orang, jumlah kunjungan ibu hamil sebanyak 4.828 orang, dan jumlah persalinan sebanyak 1.335 persalinan. Tahun 2010 sampai dengan bulan Juni jumlah persalinan sebanyak 635 kasus, sedangkan selama kegiatan penelitian berlangsung yakni bulan April sampai dengan Juni 2010 jumlah persalinan sebanyak 307 kasus, dengan perincian persalinan normal sebanyak 223 kasus, ekstraksi vakum 17 kasus, persalinan secara seksio sesaria 67 kasus. Dari 223 kasus persalinan normal, yang berhasil melakukan IMD sebesar 31 kasus $(13,9 \%)$. 
Tabel 1. Distribusi frekuensi subjek penelitian

\begin{tabular}{lcc}
\hline \multicolumn{1}{c}{ Karakteristik } & Frekuensi & $\%$ \\
\hline $\begin{array}{l}\text { Inisiasi Menyusu Dini (IMD) } \\
\text { Dilakukan }\end{array}$ & 31 & 50 \\
$\quad$ Tidak dilakukan & 31 & 50 \\
Umur & & \\
$\quad$ Tidak Berisiko & 47 & 75,81 \\
$\quad$ Berisiko & 15 & 24,19 \\
Paritas & & \\
Paritas 1 & 21 & 33,87 \\
Paritas 2-3 & 33 & 53,23 \\
$\quad$ Paritas $>3$ & 8 & 12,90 \\
Pendidikan & & \\
Dasar & 29 & 46,77 \\
Menengah & 30 & 48,39 \\
Tinggi & 3 & 4,84 \\
\hline
\end{tabular}

Tabel 1 diatas menunjukkan dari 62 subjek penelitian, jumlah ibu yang melakukan IMD dan tidak melakukan IMD sama masing-masing 50\%, sedangkan berdasarkan umur, mayoritas tidak berisiko yaitu sebesar $75,81 \%$. Pada paritas paling banyak paritas 2-3 sebesar $53,23 \%$, sedangkan berdasarkan pendidikan ibu paling banyak berpendidikan menengah yaitu $48,39 \%$.

\section{Analisis Bivariat}

Hasil uji $t$ yang dipaparkan pada Tabel 2 diatas menunjukkan bahwa ada perbedaan rerata jumlah perdarahan pasca salin berdasarkan IMD yang dilakukan. Rerata jumlah perdarahan pasca salin pada ibu yang melakukan IMD lebih sedikit dibandingkan dengan ibu bersalin yang tidak melakukan IMD. Perbedaan rerata jumlah perdarahan kedua kelompok tersebut sebesar -38,1 cc. Perbedaan tersebut signifikan secara statistik, terbukti dengan nilai $p<0,05(p=0,0000), 95 \% \mathrm{Cl}=-54,6--21,7$. Berdasarkan hasil uji diatas dapat disimpulkan bahwa IMD berpengaruh terhadap jumlah perdarahan pasca salin.

Tabel 2. Pengaruh inisiasi menyusu dini (IMD) terhadap jumlah perdarahan pasca salin

\begin{tabular}{|c|c|c|c|c|c|}
\hline Variabel & $\begin{array}{c}\text { Jumlah } \\
\text { Perdarahan } \\
\text { Mean } \pm \text { SD } \\
\end{array}$ & $\Delta$ Mean & $95 \% \mathrm{Cl}$ & $t$ & $p$ \\
\hline \multicolumn{6}{|c|}{ Inisiasi Menyusu Dini (IMD) } \\
\hline Dilakukan & $77,26 \pm 33,6$ & $-38,1$ & $-54,7--21,7$ & $-4,6$ & $0,0000^{*}$ \\
\hline Tidak dilakukan & $115,4 \pm 31,0$ & & & & \\
\hline
\end{tabular}

Hasil uji $t$ yang dipaparkan pada Tabel 2 diatas menunjukkan bahwa ada perbedaan rerata jumlah perdarahan pasca salin berdasarkan IMD yang dilakukan. Rerata jumlah perdarahan pasca salin pada ibu yang melakukan IMD lebih sedikit dibandingkan dengan ibu bersalin yang tidak melakukan IMD. Perbedaan rerata jumlah perdarahan kedua kelom- pok tersebut sebesar -38,1 cc. Perbedaan tersebut signifikan secara statistik, terbukti dengan nilai $p<$ $0,05(p=0,0000), 95 \% \mathrm{Cl}=-54,6--21,7$. Berdasarkan hasil uji diatas dapat disimpulkan bahwa IMD berpengaruh terhadap jumlah perdarahan pasca salin. 
Tabel 3. Hasil uji $t$ : Pengaruh variabel luar terhadap variabel terikat

\begin{tabular}{|c|c|c|c|c|c|c|}
\hline Variabel & $\begin{array}{c}\text { Jumlah } \\
\text { Perdarahan }\end{array}$ & AMean & \multicolumn{2}{|c|}{$95 \% \mathrm{Cl}$} & $\boldsymbol{t}$ & $p$ \\
\hline \multicolumn{7}{|l|}{ Umur } \\
\hline Tidak berisiko & $90,9 \pm 34,6$ & 22,2 & 0,54 & 43,8 & 2,0 & 0,98 \\
\hline Berisiko & $113,1 \pm 42,1$ & & & & & \\
\hline
\end{tabular}

Tabel 4. Hasil uji oneway anova: Pengaruh variabel luar terhadap variabel terikat

\begin{tabular}{lccc}
\hline Variabel & Jumlah Perdarahan pasca salin & \multirow{2}{*}{$\boldsymbol{F}$} & \multirow{2}{*}{ prob } \\
\cline { 2 - 2 } & Mean \pm SD & 2,65 & 0,08 \\
\hline Paritas & $86,9 \pm 34,8$ & & \\
Paritas 1 & $96,1 \pm 36,2$ & & \\
Paritas 2-3 & $121,7 \pm 41,8$ & \\
$\quad$ Paritas $>3$ & $108,3 \pm 35,2$ & 3,03 & 0,06 \\
Pendidikan & $86,5 \pm 38,3$ & & \\
Dasar & $78,7 \pm 8,3$ & & \\
Menengah & & & \\
Tinggi &
\end{tabular}

Hasil uji $t$ dan uji oneway anova pada Tabel 3 dan 4 diatas menunjukkan bahwa umur, paritas dan pendidikan ibu secara statistik tidak mempunyai hubungan bermakna dengan jumlah perdarahan pasca salin, yang dapat dilihat dari rentang nilai $95 \%$ confidence interval melewati angka satu. Dari hasil analisis dapat disimpulkan bahwa variabel luar yang diteliti tidak berpengaruh terhadap jumlah perdarahan pasca salin.

Tabel 5. Pengaruh variabel luar terhadap variabel bebas

\begin{tabular}{|c|c|c|c|c|c|c|}
\hline \multirow{3}{*}{ Variabel } & \multicolumn{4}{|c|}{ Inisiasi Menyusu Dini (IMD) } & \multirow{3}{*}{$x^{2}$} & \multirow{3}{*}{$p$} \\
\hline & \multicolumn{2}{|c|}{ IMD } & \multicolumn{2}{|c|}{ Tidak IMD } & & \\
\hline & $\mathbf{n}$ & $\%$ & $\mathbf{n}$ & $\%$ & & \\
\hline \multicolumn{7}{|l|}{ Umur } \\
\hline Tidak berisiko & 26 & 55,32 & 21 & 44,68 & 2,20 & 0,14 \\
\hline Berisiko & 5 & 33.33 & 10 & 66,67 & & \\
\hline \multicolumn{7}{|l|}{ Paritas } \\
\hline Paritas 1 & 9 & 42,86 & 12 & 57,14 & 1,69 & 0,43 \\
\hline Paritas 2-3 & 19 & 57,58 & 14 & 42,42 & & \\
\hline Paritas $>3$ & 3 & 37,50 & 5 & 62,50 & & \\
\hline \multicolumn{7}{|l|}{ Pendidikan } \\
\hline Dasar & 12 & 41,38 & 17 & 58,62 & 1,73 & 0,42 \\
\hline Menengah & 17 & 56,67 & 13 & 43,33 & & \\
\hline Tinggi & 2 & 66,67 & 1 & 33,33 & & \\
\hline
\end{tabular}

Pada Tabel 5 diatas menunjukkan hasil analisis hubungan antara variabel umur, paritas dan pendidikan ibu dengan variabel IMD. Hasil analisis menunjuk- kan bahwa variabel umur, paritas dan pendidikan ibu tidak memiliki hubungan yang bermakna dengan IMD yang dapat dilihat dari nilai $p>0,05$. 


\section{Analisis Multivariabel}

Tabel 6. Hasil analisis regresi linier ganda: Pengaruh IMD bersama umur, paritas dan pendidikan ibu terhadap perdarahan pasca salin

\begin{tabular}{|c|c|c|c|c|c|}
\hline Variabel & $\begin{array}{c}\text { Model } 1 \\
\text { Koefisien } \\
\mathrm{Cl} \\
p \text {-value }\end{array}$ & $\begin{array}{c}\text { Model } 2 \\
\text { Koefisien } \\
\mathrm{Cl} \\
p \text {-value }\end{array}$ & $\begin{array}{c}\text { Model } 3 \\
\text { Koefisien } \\
\mathrm{Cl} \\
p \text {-value }\end{array}$ & $\begin{array}{c}\text { Model } 4 \\
\text { Koefisien } \\
\mathrm{Cl} \\
p \text {-value }\end{array}$ & $\begin{array}{c}\text { Model } 5 \\
\text { Koefisien } \\
\mathrm{Cl} \\
p \text {-value }\end{array}$ \\
\hline \multicolumn{6}{|l|}{ Inisiasi Menyusu } \\
\hline \multicolumn{6}{|l|}{ Dini (IMD) } \\
\hline \multirow[t]{3}{*}{ Dilakukan } & $-38,1$ & $-35,8$ & $-38,4$ & $-35,3$ & $-35,8$ \\
\hline & $-54,6--21,7$ & $-52,4--19,2$ & $-54,4--22,4$ & $-51,7--18,9$ & $-52,3--18,8$ \\
\hline & $0,000^{*}$ & $0,000^{*}$ & $0,000^{*}$ & $0,000^{*}$ & $0,000^{*}$ \\
\hline \multicolumn{6}{|l|}{ Tidak dilakukan } \\
\hline \multicolumn{6}{|l|}{ Umur } \\
\hline \multirow[t]{3}{*}{ Tidak Berisiko } & & 14,3 & & & 3,6 \\
\hline & & $-5,1-33,7$ & & & $-20,4-27,6$ \\
\hline & & 0,14 & & & 0,76 \\
\hline \multicolumn{6}{|l|}{ Berisiko } \\
\hline \multicolumn{6}{|l|}{ Paritas } \\
\hline \multirow[t]{3}{*}{ Paritas 1} & & & $-14,9$ & & $-12,4$ \\
\hline & & & $-32,4-2,6$ & & $-31,0-6,1$ \\
\hline & & & 0,09 & & 0,18 \\
\hline Paritas 2-3 & & & 1 & & 1 \\
\hline \multirow[t]{3}{*}{ Paritas $>3$} & & & 17,9 & & 14,1 \\
\hline & & & $-6,9-42,6$ & & $-15,2-43,4$ \\
\hline & & & 0,15 & & 0,34 \\
\hline \multicolumn{6}{|l|}{ Pendidikan } \\
\hline \multirow[t]{3}{*}{ Dasar } & & & & 20,7 & 13,6 \\
\hline & & & & $-18,1-59,5$ & $-25,9-53,2$ \\
\hline & & & & 0,29 & 0,50 \\
\hline \multirow[t]{3}{*}{ Menengah } & & & & 4,3 & $-0,47$ \\
\hline & & & & $-34,2-42,9$ & $-39,1-38,1$ \\
\hline & & & & 0,82 & 0,98 \\
\hline Tinggi & & & & 1 & 1 \\
\hline Adjusted $R^{2}$ & 0,25 & 0,27 & 0,31 & 0,28 & 0,31 \\
\hline Constanta & 115,4 & 110,8 & 118,3 & 102,2 & 109,5 \\
\hline $\mathrm{n}$ & 62 & 62 & 62 & 62 & 62 \\
\hline
\end{tabular}

Keterangan: $*$ Signifikan $\mathrm{Cl}=$ Confidence Interval

Dari hasil analisis model, peneliti cenderung untuk memilih model 3 yang secara statistik dan praktis lebih efektif dan efisien dalam menggambarkan hubungan IMD dengan jumlah perdarahan pasca salin. Model 3 dipilih karena memiliki nilai adjusted $R^{2}$ besar dan rentang kepercayaan lebih sempit sehingga lebih signifikan. 
Berdasarkan model 3 yang terpilih sebagai model terbaik dan paling berpengaruh antara IMD terhadap jumlah perdarahan pasca salin dengan mengontrol paritas, dapat dibuat persamaan regresi. Nilai 118,3 mengindikasikan point di mana garis dapat melewati sumbu $Y$ (intercept point jumlah perdarahan pasca salin). Sedangkan nilai -38,4, -14,9 dan 17,9 adalah koefisien regresi atau slope pada garis regresi, untuk menjelaskan perubahan jumlah perdarahan pasca salin. Berdasarkan analisis di atas dapat dibuat persamaan garis regresi dengan rumus sebagai berikut:

$$
Y=a+b_{1} x_{1}+b_{2} x_{2}+\ldots \ldots \ldots+b_{k} x_{k}
$$

Keterangan :

$\mathrm{Y}=$ jumlah perdarahan pasca salin

$\mathrm{a}=$ nilai konstanta/intercept

$\mathrm{b}=$ nilai koefisien regresi

$\mathrm{x} 1=$ variabel inisiasi menyusu dini (IMD)

$\mathrm{x} 2$ = variabel paritas ibu

Sesuai dengan rumusan di atas maka dapat diformulasikan dalam persamaan regresi linier sebagai berikut:

Jumlah perdarahan pasca salin $=118,3+-38,4$ (IMD) $+-14,9+17,9 \quad$ (Paritas 1 dan Paritas >3)

Dengan model persamaan tersebut maka dapat diperkirakan perubahan jumlah perdarahan pasca salin dengan menggunakan variabel IMD dan paritas ibu. Pada ibu yang melakukan IMD akan terjadi perubahan jumlah perdarahan pasca salin sebesar 38,4 cc. Pada ibu yang melakukan IMD akan terjadi perubahan jumlah perdarahan pasca salin sebesar 14,9 cc dan 17,9 cc setelah dikontrol dengan variabel paritas 1 dan paritas $>3$. Dengan kata lain, ibu yang tidak melakukan IMD jumlah perdarahan pasca salin akan berkurang sebesar $118,3 \mathrm{cc}\left[118,3+\left(-38,4^{*} 0\right)\right]$. Apabila ibu melakukan IMD akan terjadi pengurangan jumlah perdarahan pasca salin sebesar nilai konstanta ditambah dengan koefisien regresi dari IMD [118,3+($38,4 * 1)$ ]. Apabila dikontrol lagi dengan variabel paritas akan mengurangi jumlah perdarahan pasca salin sebesar nilai konstanta ditambah dengan koefisien regresi dari IMD dan koefisien regresi dari paritas yaitu $[118,3+(-38,4 * 1)+(-14,9 * 1)+(17,9 * 1)]$.

\section{HASIL DAN PEMBAHASAN}

Hasil analisis bivariate menunjukkan bahwa IMD mempunyai hubungan yang bermakna dengan jumlah perdarahan pasca salin. Hipotesis yang menyebutkan rata-rata jumlah perdarahan pasca salin pada ibu yang menjalani IMD lebih sedikit dibandingkan rata-rata jumlah perdarahan pada ibu yang tidak menjalani IMD dapat diterima. Penelitian ini menunjukkan beda rerata jumlah perdarahan pasca salin sebesar $-38,1 \mathrm{cc}$ dengan nilai $p<0,05$ ( $p=$ 0,0000) dan $C / 95 \%=-54,6--21,7$. Hasil penelitian menunjukkan bahwa IMD dapat mengurangi terjadinya perdarahan pasca salin sebesar $25 \%$. Secara statistik IMD mempunyai hubungan yang bermakna dengan jumlah perdarahan pasca salin, namun hasil penelitian ini menunjukkan bahwa semua perdarahan yang terjadi kurang dari $200 \mathrm{cc}$, baik pada ibu yang menjalani IMD maupun pada ibu yang tidak menjalani IMD. ${ }^{9,18,19,20}$

Adanya isapan bayi pada puting susu ibu menyebabkan oksitosin akan keluar lebih banyak. Hal ini menguntungkan karena otot-otot polos rahim akan terus berkontraksi. Artinya rahim akan berkontraksi lebih kuat sehingga perdarahan pasca salin dapat dicegah. ${ }^{22}$ Kadar oksitosin ibu yang menyusui meningkat dan akan membantu rahim ke ukuran semula karena dapat membuat otot-otot di sekitar rahim mengkerut. ${ }^{11}$

Hasil analisis variabel luar terhadap variabel terikat menunjukkan bahwa umur tidak mempunyai hubungan yang bermakna dengan jumlah perdarahan pasca salin dengan nilai $p>0,05(p=0,98) \mathrm{Cl} 0,54$ - 43,8. Umur ibu yang dianggap berisiko untuk terjadinya perdarahan pasca salin adalah umur $\leq 19$ tahun dan $\geq 36$ tahun. ${ }^{23}$ Umur diatas 35 tahun mempunyai kemungkinan besar terjadi perdarahan 
pasca salin, dan semakin tua umur semakin besar risikonya. ${ }^{23}$ Hasil temuan ini tidak sejalan dengan penelitian sebelumnya yang menemukan perdarahan pasca salin cenderung meningkat dengan bertambahnya umur ibu. ${ }^{24}$ Berbeda juga dengan hasil penelitian yang mengatakan bahwa kejadian perdarahan pasca salin lebih tinggi pada ibu yang lebih tua dan pada ibu yang persalinannya lebih dari tiga. ${ }^{25}$ Wanita hamil diatas umur 35 tahun memiliki risiko komplikasi selama kehamilan dan persalinan yang lebih tinggi dibandingkan umur kurang dari 20 tahun. ${ }^{27}$ Temuan ini juga berbeda dengan hasil penelitian terdahulu yang menyatakan bahwa perdarahan pasca salin terjadi sebagian besar diatas umur 35 tahun. ${ }^{28} \mathrm{Umur}$ nullipara $\geq 35$ tahun secara praktis berhubungan dengan perdarahan pasca salin. ${ }^{29}$ Sementara penelitian lain menyatakan umur ibu yang kurang dari 20 tahun berisiko karena belum siap secara medis maupun mental sedangkan umur ibu yang lebih dari 35 tahun mengalami kemunduran fisik untuk menghadapi kehamilan atau persalinan. ${ }^{30}$ Kondisi tersebut merupakan predisposisi untuk terjadi perdarahan pasca salin.

Ketidaksesuaian hasil penelitian ini dengan penelitian-penelitian sebelumnya kemungkinan disebabkan oleh adanya kebijakan program pemerintah dalam upaya menekan angka kematian ibu akibat perdarahan pasca salin. Berkaitan dengan upaya tersebut RSUD Sleman telah menetapkan manajemen aktif kala III dengan pemberian oksitosin sebesar 10 international unit (IU) secara intramuskular sebagai prosedur tetap yang harus dijalankan pada semua kasus persalinan normal baik pada ibu yang melakukan IMD maupun yang tidak melakukan IMD. Dalam penelitian ini umur tidak mempengaruhi jumlah perdarahan pasca salin karena umur tidak secara langsung menentukan seseorang untuk melakukan IMD, namun berpengaruh terhadap pemahaman seseorang. Umur yang lebih muda cenderung lebih aktif dan mudah menerima informasi baru terutama dalam kesehatan keluarga khususnya informasi tentang IMD. Kondisi ini akan berpengaruh pada pengetahuan, pemahaman dan kemauan yang dimiliki serta dukungan dari petugas penolong persalinan untuk melaksanakan IMD.

Hasil penelitian menemukan paritas tidak mempunyai hubungan yang bermakna dengan jumlah perdarahan pasca salin dengan nilai $p<0,05(p=$ $0,14)$. Penelitian ini mendukung penelitian sebelumnya yang menemukan bahwa paritas tidak bermakna secara statistik terhadap perdarahan pasca salin. ${ }^{(24)}$ Hal ini tidak sesuai dengan hasil penelitian terdahulu yang menyatakan bahwa insidensi perdarahan pasca salin sebesar 2,7\% terjadi pada ibu dengan paritas tinggi dan meningkat 4 kali lipat dibandingkan dengan ibu paritas rendah. ${ }^{31}$ Penelitian lain menunjukkan ada hubungan bermakna kejadian perdarahan pasca salin $\geq 500 \mathrm{ml}$ dan $\geq 1000 \mathrm{ml}$ pada wanita nullipara yang melahirkan secara vaginal. Kejadian perdarahan pasca salin pada ibu yang mengalami perdarahan $\geq$ $500 \mathrm{ml}$ sebesar $19 \%$ dan perdarahan $\geq 1000 \mathrm{ml}$ sebesar 4,2\%. ${ }^{29}$ Paritas tinggi merupakan salah satu faktor risiko terjadinya perdarahan pasca salin yang disebabkan oleh atonia uteri, hal ini terjadi karena kondisi miometrium dan tonus otot sudah tidak baik lagi sehingga menimbulkan kegagalan kompresi pembuluh darah pada tempat implantasi plasenta. ${ }^{26}$

Ketidaksesuaian hasil penelitian ini dengan penelitian-penelitian terdahulu kemungkinan juga disebabkan oleh adanya intervensi pemberian obat untuk mengefektifkan kontraksi uterus pada semua ibu bersalin setelah kala III berakhir dengan injeksi metilergometrin sebesar $0,2 \mathrm{mg}$ secara intramuskular yang sudah merupakan prosedur tetap di RSUD Sleman. Hal tersebut dilakukan sebagai tindakan antisipatif terhadap munculnya perdarahan pasca salin, karena paritas tinggi merupakan salah satu faktor risiko terjadinya perdarahan pasca salin. Untuk mencegah hal ini terjadi maka bidan di RSUD Sleman lebih waspada pada ibu yang melahirkan anak ke empat atau lebih, terutama untuk pemberian oksitosin yang diperlukan sesegera mungkin dalam 1 menit setelah kelahiran bayi, sehingga uterus dapat berkontraksi dengan baik. 
Hasil analisis terhadap variabel pendidikan ibu menunjukkan bahwa pendidikan tidak mempunyai hubungan yang bermakna dengan jumlah perdarahan pasca salin dengan nilai $p<0,05(p=0,15)$. Temuan ini mendukung penelitian sebelumnya yang mengatakan bahwa pendidikan rendah bukan sebagai faktor risiko terhadap kejadian perdarahan pasca salin. ${ }^{19} \mathrm{Hal}$ ini disebabkan pendidikan tidak secara langsung mempengaruhi jumlah perdarahan namun dari perilaku ibu dalam melakukan tindakan IMD.

\section{KESIMPULAN DAN SARAN}

Berdasarkan hasil penelitian dapat disimpulkan bahwa rata-rata jumlah perdarahan pasca salin pada ibu yang melakukan IMD lebih sedikit dibandingkan dengan rata-rata jumlah perdarahan pada ibu yang tidak melakukan IMD. Sehingga disarankan perlu adanya sosialisasi yang lebih intensif kepada para ibu sejak perawatan antenatal agar dapat memberikan ASInya seawal mungkin, menempatkan bayi seawal mungkin secara tepat dengan posisi yang benar sehingga terjadi skin contact lebih awal, perlu melibatkan keluarga untuk membantu ibu melaksanakan IMD dan komitmen yang kuat dari petugas penolong persalinan untuk memfasilitasi ibu bersalin dalam melakukan inisiasi menyusu dini.

\section{DAFTAR PUSTAKA}

1. Depkes RI. Asuhan persalinan normal asuhan esensial persalinan (Edisi ketiga). Jakarta: JNPKKRPOGI; 2007.

2. Islam, A., Siraj, A. \& Arif, N. Pasca salin haemorrhage prophylaxis: Comparison of the efficacy of misoprostol and ergometrine in cesarian delivery. Professional Medical Journal, 2008;15(3):323-7.

3. FIGO-ICM. Prevention and treatment of post partum haemorrhage new advances for low resource setting. London: FIGO; 2006.

4. AbouZahr, C. Antepartum and pasca salin haemorrhage In : Murray CJL, Lopes AD, eds. Health dimensions of sex and reproduction (165-90). Boston: Harvard University Press; 1998.

5. WHO. Mother-baby package. (WHO/RHT/MSM/ 94.11.Rev1.). Geneva: WHO; 1998.
6. Shane, B. Preventing pasca salin hemorrhage: managing the third stage of labor. Outlook (Maternal and Neonatal Health Special Issue). Seattle: PATH; 2001;19 (3):1-8.

7. Prawirohardjo, S. Buku acuan nasional pelayanan kesehatan maternal dan neonatal (Edisi kedua). Jakarta: JNPKKR-POGI dan YBPSP; 2001.

8. Depkes RI. Pelatihan pelayanan obstetri neonatal emergensi dasar. Jakarta: Direktorat Jenderal Bina Kesehatan Masyarakat dan Kesehatan Keluarga; 2004.

9. Suradi, R. Manajeman laktasi. Jakarta. Perkumpulan Perinatologi Indonesia; 2004.

10. Depkes RI. Pedoman pelaksanaan pekan ASI sedunia. Jakarta: Kementrian Negara Pemberdayaan Perempuan Indonesia; 2007.

11. Roesli, U. Inisiasi menyusu dini plus ASI eksklusif. Jakarta: Pustaka Bunda; 2008.

12. Cox, S. Breastfeeding with confidence. Jakarta: Elek Media Komputindo; 2006.

13. Dinas Kesehatan Propinsi D.I. Yogyakarta. Profil kesehatan Propinsi D.I. Yogyakarta. Yogyakarta: Dinkes Propinsi DIY; 2008.

14. Irawati, A. \& Junadi, P. Pola inisiasi dan faktor-faktor yang berhubungan dengan keterlambatan ASI di Indonesia. Gizi Indonesia, 1996;121:80-93.

15. Leung, A. \& Sauve, R. Breast is best for babies. National Medical Association Journals, 2005;97(7):1010-9.

16. Pradjatmo, H. \& Pranoto, I. Pemberian oksitosin sebagai uterotonika profilaksis untuk mencegah perdarahan pasca persalinan. Yogyakarta: FK Universitas Gadjah Mada; 1988.

17. Purwanti, H. Konsep penerapan ASI eksklusif: Buku saku untuk bidan. Jakarta: EGC; 2004.

18. Depkes RI. Buku pedoman pengenalan tanda bahaya pada kehamilan, persalinan dan nifas. Jakarta: Direktorat Jenderal Pembangunan Masyarakat Desa; 2000.

19. Abdullah, S.M. Faktor-faktor yang berhubungan dengan kejadian perdarahan pasca salin di Kota Palu. Tesis. Yogyakarta: Program Pasca Sarjana Universitas Gadjah Mada; 2002.

20. Tsu, V.D., Mai, T.T.P., Nguyen, Y.H. \& Luu, H.T.T. Reducing pasca salin hemorrhage in Vietnam: assessing the effectiveness of active Management of third stage labor. J Obstet Gynaecol Res, 2006;32(10): 489-96. 
21. Wiknjosastro, H. Ilmu kebidanan. Jakarta: Yayasan Bina Pustaka Sarwono Prawirohardjo; 2007.

22. Jolly, A., Sebire, N., Harris, J., Robinson, S., \& Regan, $\mathrm{L}$. The risk associated with pregnancy in women age 35 year or older. Hum Reprod, 2000;15(11): 2433-7.

23. Sipila, P., Sorri, A.L.H., Oja, H. \& Wendt, L.V. Perinatal outcome of pragnancies complicated by vaginal bleeding. BJOG, 1992;99: 959-63.

24. Joke, M.J., Bais, Eskes, M., Pel, M., Gouke, J., Bonsel \& Bleker O.P. Pasca salin haemorrhage in nulliparous women: incidence and risk factors in low and high risk women a Dutch populationbased cohort study on standard (e"500 ml) and severe $\left(e^{\prime \prime} 1000 \mathrm{ml}\right)$ pasca salin haemorrhage. Obstet Gynecol Reprod Biol, 2004;115:166-72.
25. Sulistiyowati, N., Ronoatmodjo, S. \& Tarigan, H.L. Kematian perinatal hubungannya dengan faktor praktek kesehatan ibu selama kehamilan di Kota Bekasi tahun 2001. Jakarta: Pusat Penelitian Ekologi Kesehatan UI; 2001.

26. Fuchs, K., Peretz, B.A., Marcovici, R. \& Paldi, E. The grand multipara is the a problem. In Cuningham, F.G., Gant, N.F., Leveno, K.J., Gilstraf, L.C., Hauth, J.C. \& Wenstrom, K.D. Obstetri Williams, vol. 1. Edisi 21. Jakarta: EGC; 1985.

27. Ibe, O.E., Austin, T., Sullivan, K., Fabanwo, O., Disu, E. \& Costello, A.M. A comparison of kangaroo mother care and conventional incubator care for thermal regulation of infants < 2000 gram in Nigeria using continuous ambulatory temperature monitoring. Ann Trop Paediatr, 2004;24(3): 245-51. 